\title{
Border Crossings: On the Boundary of the Physician-Patient Relationship
}

\section{David Loxterkamp, $M D$}

Physicians are trained to divorce personal feelings from professional duty and to avoid those patient encounters in which we play a dual or compromised role. Yet in practice, especially in those encounters where the physician-patient relationship is our chief therapeutic tool, emotion and conflict often arise. Rather than fearing their intrusions, we should understand them to be inevitable, informative, and indispensable means to the provision of high-quality patient care and professional selffulfillment.

Sunday at dusk.

I am driving back from Boston after a conference for teachers in family medicine. In Portsmouth the road rises sharply above the Piscataqua River, where its industrial mouth forms a natural border between New Hampshire and Maine. Suddenly I realize that this I-95 bridge-perched on the margins of a wider world and my adopted home and between the lights of higher education and the shifting shoals of private practice-spans more than a geographic frontier.

Though my eyes lock on the center line, my mind veers to thoughts from the final workshop, an exploration of ethical boundaries in patient care. How cleanly we wove through the familiar snares: news of an associate's sexual impropriety, favors parceled to special patients, promises we make but cannot keep, the dangers of self-disclosure, and encroaching demands of work on family life. All cases were perfunctorily dispatched by my seasoned colleagues while I lay mired in the first scenario: a physician has just examined his neighbor's child for bruising. On questioning, the boy alleges that his father struck him. What must the physician do?

For me, the answers are not academic. Tomorrow I will address a grand jury on behalf of my

Submitted 25 February 1998.

From a private practice. Address reprint requests to David Loxterkamp, MD, 15 Salmond St, Belfast, ME 04915. friend, charged with gross sexual misconcuct. Both victim and accused are patients of mine; I know their stories well. I am privy to the child's profound immaturity, to her father's paranoid depression, to the secondary gain if charges were to proceed. I respect the innocence of youth, the epidemic of child abuse, and the need to take all reports seriously. I know something about false memory and the nature and condition of suggestibility and how gossip and appearances can ruin a newcomer to town.

Tomorrow, before a jury of my peers, I will be asked to cross the boundaries of professional duty, personal loyalty, and civic obligation. After 13 years in a small town, I know the gravity of my position, the nakedness of my exposure. There is no one who regards me as simply "the doctor." I know my patients as neighbors, parishioners, members of my wife's French group, teachers of our children. Every day I cross lines for them so I can trim a medical expense, allay a fear, or lend a neighborly hand.

And so do you, physicians who remain distant by virtue of your academic position, an analytic eye, or another life in the suburbs. Though freed from the conflict of dual relationships, you cross a more tenuous tract: the thin edge between one's guarded self and the suffering. What passes through your mind as organ systems founder in your capable hands or patients weep inconsolably at the news of cancer? Do you pull out all stops or brood in awkward silence? How do you partition your guilt, anger, pride, or lust? Yet without feeling, how can we be drawn to the patient's pitiable plight or recognize it as our own? By human bonds the physician is drawn to listen more intently, offer another remedy or referral, trace the wispy outlines of hope, telephone at the tail of an unrelenting day, read further into the night, and ultimately reap (more often than we deserve) that singular prize of a patient's gratitude.

In the vagaries of patient care, the physician is 
revealed...though we use every available means to hide. By virtue of our crammed waiting rooms, feverish schedules, obfuscating lingo, concealing gowns, and dazzling technology, we bar the door between ourselves and "the other." Who among us does not unfold the fetal monitor strip before pressing the hand of the patient in labor? Whose gaze can avoid the skips and scurries on the cardiac monitor, or examine oxygen saturations and blood pressure readouts, or sift the sediment in a catheter bag before meeting those darting eyes in the intensive care bed? We approach patients like the Wizard of $\mathrm{Oz}$, who wields his knobs and levers from behind the drawn curtain, activating great bursts of steam and belching flame, projecting a stern and ominous image, and speaking in terse and resonant tones, "Do not arouse the wrath of the Great and Powerful Oz. I said come back tomorrow." And when a protest emerges, he retorts, "Do you presume to ctiticize the Great Oz? You ungrateful creatures! Consider yourself lucky that I've given you audience tomorrow instead of in twenty years."

In spite of ourselves, and because of it, we are pricked by the patient's misery. Our compassion and worry seep through; powerlessness, frustration, and anger brim over. We become painfully self-aware, like the wizard whom Toto has exposed. And still we insist, "Pay no attention to the man behind the curtain. The grate $\mathrm{Oz}$ has spoken."

The physician-poet William Carlos Williams ${ }^{1}$ knew the dangers all of us face:

I'm sure most of us docs work hard and try to do the best we can. But I'm not sure we don't hurt a lot of people with our manners, our sour moods, or the big rush we're in. I don't have answers.... But you're on thin ice when you hear yourself apologizing for yourself and begging for the next guy's pity: See me, how hard I work, and the good I do, so shut up if you have any bellyaching complaints. That's the most tempting line for me, the one I take when I'm in trouble.

Training is poor preparation for the interpersonal taxation of patient care. Students are shielded by the blur of 5-week rotations and a homage to the gods of Knowledge and Skill. At graduation, we don the cloak of Hippocrates but cannot fathom his injunction to live chaste and religious lives or to regard the physician-patient relationship as a sacred trust. We take the oath without having tested our vows to safeguard the patient's secrets, avoid taking sexual advantage ("be they slave or free"), and honor the territorial boundaries (by letting surgeons cut, "even for the stone"). ${ }^{2}$

We walk in the pedagogical shadows of Sir William Osler, whose disciples still advise a judicious measure of obtuseness when dealing with patients. Phrases such as emotional distance, detached concern, and clinical objectivity seem a reasonable defense against the fear of becoming obsessed, paralyzed, or consumed by our work.

But now, as our hearts beat inside a clinician's coat, we realize how easily we are distracted from the diagnostic chase. Patients draw us in, entreat us to become their field general, cheerleader, confessor, parent. Their demands fall outside the economists' clean scale, the one that measures service in the number of patient contact hours, that records data derived only from a code book, and that peels each procedure from its physicianpatient relationship, as if technician and tissue were interchangeable parts.

I can tell you, family physician or small-town doc, it is impossible to leave your stethescope and prescription pad at the office. And the rest of us will soon discover that the lofty goals of medicine-to cure illness and relieve suffering-go wanting when we skulk behind our journal articles, laboratory results, and stern, studied postures. In the long haul, patients need more than an antibiotic or coronary stent. They want a physician who cares about them, who is willing to abandon the pedestal or veil to stumble on words of condolence or affection. They need a physician who will wade into their worries and find rest in their deepest despair.

Every day, on hospital rounds and during office hours, we discover the very embodiment of courage, grace, and redemption. It becomes our privilege to offer patients what they might confuse as friendship, lacking any approximation. By forsaking the usual boundaries, we can share in the experiences that invigorated Dr. Williams' long career: the exhilaration of looking into things deeply, the recognition of ourselves in every difficult patient, and the gratitude of those who have been shown the hidden secrets of their private lives. ${ }^{3}$

My practice has become a constant border crossing, for I have not one job to do, but many. I slip back and forth between roles: today I will at- 
tempt a cure, but tomorrow only listen, reassure, or admonish. I must weigh, with a moral as well as clinical sensibility, the burden of treatment on a fixed income. I will slant my patient's disabillity report, interpret an advanced directive, balance desire against the safety of returning home from the hospital or staying behind the wheel or reentering an abusive situation.

We are not border police but night raiders in a no-man's-land. We go alone in the shadows of self-doubt. We clip the barbed wire of our privilege and status to spend a moment with our patients in the desperate details of their lives. The more successful among us will acquire solid bearings, a healthy respect for the conditions, a sense of timing, the needed support. Our approach becomes more evenly balanced between "steadiness" and "tenderness," in the words of the 19th century ethicist-physician, Thomas Percival. It necessarily taps the "affectionate bonds" between physician and patient that, according to Gayle Stephens, defines us as family physicians and earns for us whatever moral credibility we wield. ${ }^{4}$

Errors in judgment will be made, and not only because of our inexperience. Intellect and ego will delude us into believing that we are satisfying only the patients' needs. Those who open their hearts to the clinical encounter will know the bane of running late, getting overly involved, fostering dependence, raising false hope, and setting the unwanted precedent. But we know this, too: that only from the margins can we see both sides-the shared predicament of patient and physician.

As I cross the borders, I tote along Dr. Williams' classic tales and recall his humble reply when asked how he might improve the quality of medical education. "I can only come up with my shame, as I remember it, and its sources," he said. "I wish we had medical ethics courses that pushed us to take a hard look at ourselves.... the way a physician's general attitude toward people, his personal decency and his view of what life means, can influence the way he practices medicine."1

The heart, principal cause of clinical death, is our only hope of survival in a medical life. It will motivate us, inform us, and lead us more deeply into our patients' lives, where we can find the miracles to lift a lagging spirit.

Monday all worry came to naught. I met the bright, searching eyes of the jury; in them I found the theater director whose complicated myocardial infarction I helped to manage, the adolescent whom I delivered of a premature infant and from the arms of her battering lover, and the bank teller who only last week confessed to me such secrets that no one should harbor alone. What might they think they owe me; what do I owe them in return?

Though the prosecutor denied me a podium, she also spared my testimony in areas of professional privilege. It was the jurors themselves who were unstinting in their pursuit of the only real evidence at stake: a child's memory. In the end they voted to dismiss all charges.

Both families still call me their doctor. And I wonder, of course, whether justice was served. That truth, like everything we grasp in the guesswork of clinical care, often lies just beyond reach in the borderland between fact and prejudice, certainty and paralytic doubt. We have only our best intentions, and the insistence that truth knows no boundary.

\section{References}

1. Coles R. The call of stories: teaching and the moral imagination. Boston: Houghton Mifflin, 1989:109.

2. Lloyd GE, editor; Chadwick J, Mann WN, Withington ET, Lonie IM, translators. Hippocratic writings. New York: Viking Penguin, 1978:67.

3. Williams WC; Coles R, editor. The doctor stories. New York: New Directions, 1984.

4. Stephens G. Acts of endearment: attending to the affectional bonds between physicians and patients. Can Fam Physician 1992;38:2842-5. 